http://dx.doi.org/10.1590/0104-07072017002700015

\title{
AGING AND INDIVIDUAL VULNERABILITY: A PANORAMA OF OLDER ADULTS ATTENDED BY THE FAMILY HEALTH STRATEGY ${ }^{1}$
}

\author{
Keylla Talitha Fernandes Barbosa², Kátia Neyla de Freitas Macêdo Costa ${ }^{3}$, Maria de Lourdes de Farias Pontes, \\ Patrícia Serpa de Souza Batista ${ }^{5}$ Fabiana Maria Rodrigues Lopes de Oliveira ${ }^{6}$, Maria das Graças Melo Fernandes ${ }^{7}$
}

\footnotetext{
${ }^{1}$ Article extracted from the dissertation-Vulnerabilidade física, social e programática de idosos atendidos na Atenção Primária de Saúde do município de João Pessoa, Paraíba, presented to the Programa de Pós-Graduação em enfermagem da Universidade Federal da Paraíba (UFPB) in 2015.

2 Ms. C. in Nursing. Programa de Pós-Graduação UFPB. João Pessoa, Paraíba, Brazil. E-mail: keyllafernandes@gmail.com

${ }^{3}$ PhD in Nursing. Professor, Department of Clinical and Surgical Nursing, UFPB. João Pessoa, Paraíba, Brazil. E-mail: katianeyla@ hotmail.com

${ }^{4}$ Ph.D. in Health Sciences. Professor, Department of Public Health Nursing and Psychiatry, UFPB. João Pessoa, Paraíba, Brazil. E-mail: profa.lourdespontes@gmail.com

${ }^{5}$ Ph.D. in Education. Professor Department of Public Health Nursing and Psychiatry UFPB. João Pessoa, Paraíba, Brazil. E-mail: patriciaserpa@oi.com.br

${ }^{6}$ Ms. C. in Nursing. Programa de Pós-Graduação, UFPB. João Pessoa, Paraíba, Brazil. E-mail: fabianarodriguesenf@yahoo.com.br

${ }^{7}$ Ph.D. in Sociology. Professor, Department of Clinical and Surgical Nursing UFPB. João Pessoa, Paraíba, Brazil. E-mail: graacafernandes@hotmail.com
}

\section{ABSTRACT}

Objective: identifying conditions of individual vulnerability in older adults and investigating the relationship with health indicators through a household survey.

Method: a descriptive cross-sectional study conducted with 368 older adults attended by the Family Health Strategy. Data collection was performed through a structured interview, supported by instruments that include sociodemographic characterization, health indicators and the Vulnerable Elders Survey. A descriptive data analysis and Person's chi-square test were also performed.

Results: a prevalence of $52.2 \%$ individual vulnerability was found among older adults, in addition to an association with health problems, negative self-perception of health, difficulty with mobility and in performing activities of daily living.

Conclusion: identifying vulnerability among the aged population is a relevant initiative for the adequacy of health policies and programs that prioritize the promotion of aging with the maintenance of functional capacity.

DESCRIPTORS: Vulnerability health. Older adults. Primary health care. Nursing.

\section{ENVELHECIMENTO E VULNERABILIDADE INDIVIDUAL: UM PANORAMA DOS IDOSOS VINCULADOS À ESTRATÉGIA SAÚDE DA FAMÍLIA}

\section{RESUMO}

Objetivo: identificar as condições de vulnerabilidade individual em idosos e investigar a relação com os indicadores de saúde por meio de um inquérito domiciliar.

Método: delineamento descritivo, de corte transversal, realizado com 368 idosos atendidos pela Estratégia Saúde da Família. A coleta de dados deu-se através de entrevista estruturada, subsidiada por instrumentos que incluem a caracterização sociodemográfica, indicadores de saúde e o Vulnerable Elderly Survey. Realizou-se, ainda, a análise descritiva dos dados e o teste qui-quadrado de Pearson.

Resultados: há prevalência de 52,2\% de vulnerabilidade individual entre os idosos, além de uma associação com problemas de saúde, autopercepção negativa de saúde, dificuldade na mobilidade e no desempenho de atividades da vida diária.

Conclusão: a identificação da vulnerabilidade entre a população idosa é uma iniciativa relevante para a adequação de políticas e programas de saúde que priorizem a promoção do envelhecimento com manutenção da capacidade funcional.

DESCRITORES: Vulnerabilidade em saúde. Idoso. Atenção primária à saúde. Enfermagem. 


\title{
EL ENVEJECIMIENTO Y LA VULNERABILIDAD INDIVIDUAL: UN PANORAMA DE LOS ANCIANOS ASOCIADOS A LA ESTRATEGIA DE SALUD FAMILIAR
}

\begin{abstract}
RESUMEN
Objetivo: identificar las condiciones de vulnerabilidad individuales en los ancianos y investigar la relación con los indicadores de salud a través de una encuesta de hogares.

Método: diseño descriptivo, transversal, realizado con 368 ancianos asistidos por la Estrategia Salud de la Familia. La recolección de datos se realizó a través de una entrevista estructurada, con el apoyo de instrumentos, incluyendo los indicadores sociodemográficos, de salud y Vulnerable Elderly Survey. También llevó a cabo el análisis descriptivo y la prueba de chi-cuadrado de Pearson.

Resultados: existe una prevalencia de 52,2\% de la vulnerabilidad individual entre los ancianos, así como una asociación con problemas de salud, la salud autopercepción negativa, dificultad en la movilidad y el desempeño de las actividades de la vida diaria.

Conclusión: la vulnerabilidad de la identificación de los ancianos es una iniciativa importante para la adecuación de las políticas y programas de salud que se centran en la promoción del envejecimiento con el mantenimiento de la capacidad funcional.

DESCRIPTORES: Vulnerabilidad en salud. Ancianos. Atención primaria de salud. Enfermería.
\end{abstract}

\section{INTRODUCTION}

The aging process in many countries has taken place in a slow and gradual manner, thereby making adjustments in the provision of social services, social security and health services possible. In Brazil, however, this process has been occurring in an accelerated manner, especially since the beginning of the $21^{\text {st }}$ Century, associated with important social and economic transformations as well as a change in the epidemiological profile and in the demands of health services. ${ }^{1}$ Such a change implies in the increase of direct and indirect costs for the public system and more efforts in planning policies, programs and actions aimed at active and healthy aging. ${ }^{2}$

Due to its magnitude, aging can be considered an important public health issue. Because it is a multidimensional process that is influenced by several intrinsic and extrinsic factors, approaches that are essentially biological are not sufficient or satisfactory for designing public policies adapted to the real demands of this group. For this reason, it is imperative that matters related to older people are analyzed from a more comprehensive perspective. ${ }^{3}$

In this context, the concept of vulnerability in health is approached with the purpose to bring the abstract elements related to the processes of aging and illness to more concrete, specific and multidimensional plans. Unlike risk studies, investigations conducted in the theoretical perspective of vulnerability express the potential for illness/ disease, non-disease/illness and coping related to each individual, seeking synthesis of three levels individual, social and programmatic. ${ }^{4}$
In the context of gerontology, the concept of vulnerability encompasses the status of individuals or groups who for some reason have a reduced self-determination ability, and may experience difficulties in protecting their own interests due to deficits in power, intelligence, education, resources, strength, or other attributes. Aging implies an increased risk for the development of biological or individual vulnerability of socioeconomic and psychosocial natures due to the typical biological decline of senescence, which interacts with sociocultural processes and with the cumulative effects of poor education, income and health conditions throughout life. These conditions may cause a significant impact on older adults, especially favoring individual vulnerability, and more strongly associated with biophysiological components. ${ }^{3}$

Despite the increasing number of scientific publications involving this topic, it can be observed that there is still insufficient knowledge about the understanding of older adult vulnerability. Thus, the relevance of this study particularly lies in its potential to generate important information for guiding the planning and practice of elderly care, both at the research locus and in other services and settings such as Nursing, which requires theoreticalscientific knowledge, technical skills and abilities, in addition to other capacities from its workers. ${ }^{5}$

It is assumed that identifying individual vulnerability in older people and knowledge of the aspects inherent to the aging process, as well as the conditions associated with this process are important empirical indicators that can justify the 
allocation of resources and care programs toward those with greater possibilities of adverse outcomes, such as reduced functional capacity and death. ${ }^{6}$

Thus, the following objectives were established for this study: identifying individual vulnerability conditions in older persons and investigating the relationship between individual vulnerability and health indicators among the older adults participating in the study.

\section{METHOD}

This is a cross-sectional household survey implementing a descriptive, observational design developed among older adults attended by the Family Health Strategy of the municipality of João Pessoa, Paraíba, Brazil.

The study population was comprised of all individuals over the age of 60 registered in the Primary Care Information System of said municipality, corresponding to 24,328 older adults registered in 56 Family Health Units across five health districts. The stratified proportional sampling technique was used, which took into account the five health districts as strata. The following formula was considered for the composition of the sample: $\mathrm{n}=\mathrm{Z} 2 \mathrm{PQ} / \mathrm{d} 2$, where $\mathrm{n}=$ minimum sample size; $\mathrm{Z}=$ reduced variable; $\mathrm{P}=$ probability of finding the studied phenomenon; $\mathrm{Q}=1-\mathrm{P} ; \mathrm{d}=$ desired accuracy, calculated on the basis of a $5 \%$ margin of error; and $\mathrm{p}=50 \%$, resulting in 380 individuals.

Inclusion criteria were older adults of both genders residing in the health district under study, in addition to those with preserved cognitive conditions as measured through the Mini Mental State Examination (MMSE), considering a cutoff score over 13 for illiterates and over 17 for literates. ${ }^{7}$ Those with impaired hearing or speech problems that made communication difficult or impossible to carry out the evaluation were excluded. Considering these aspects, the final sample consisted of 368 older adults.

Initially, each participant read and signed the Free and Informed Consent Form. Next, data collection was carried out between February and April 2014 by subsidized researchers with the assistance of Community Health Agents who worked in the selected Family Health Units. The information was collected from a single interview in the respective residences of the older adults, without help from their relatives and according to their availability. In order to operationalize the structured interview, two instruments were used: the first one consisted of a questionnaire considering sociodemographic variables (age, gender, marital status, years of schooling, family income) and health indicators (self-reported morbidities, self-assessment of health, as well as dichotomous issues about mobility as well as basic and instrumental activities of daily living). The second consisted of the Vulnerable Elders Survey (VES-13), which was translated and transculturally adapted for the Brazilian reality. ${ }^{8}$

The Vulnerable Elders Survey (VES-13) is a simple, easy-to-apply tool with the goal to identify vulnerable older adults living in the community. The variables strongly associated with the risk of vulnerability presented in this instrument are: age, self-assessment of health and indicators related to the presence of physical limitation and functional disability, totaling 13 items with scores ranging from a minimum value of zero and a maximum of ten assigned. Older adults who score less than or equal to three in this assessment are considered non-vulnerable. ${ }^{8}$

The data analysis was carried out using a quantitative approach, and univariate descriptive statistics for all variables, including measures of frequency, position and dispersion. In order to compare the main categorical variables among the different groups, the study population was divided into vulnerable and non-vulnerable older adults, identified through the Vulnerable Elders Survey (VES13). Pearson's chi-square test with a $95 \%$ significance level was used. The Statistical Package for the Social Sciences (SPSS) version 20.0 was also used as it was suitable for reaching the study objectives, allowing for accuracy and generalizing its results.

It should also be noted that ethical aspects regulating research involving human beings set forth by Resolution 466/2012 of the CNS/MS/ BRAZIL were observed throughout the research process, especially in the empirical information gathering phase and especially involving secrecy and confidentiality of information. ${ }^{9} \mathrm{We}$ also point out that the research project in question was approved by the Research Ethics Committee of the Health Sciences Center of the Federal University of Paraíba, under protocol number 0658/13 and CAAE: 23958013.0.0000.5188 of December 10, 2013. 


\section{RESULTS}

Table 1 - Relationship between older adults according to the presence or absence of individual vulnerability and sociodemographic variables. João Pessoa, Paraíba, Brazil, 2014 (n = 368)

\begin{tabular}{|c|c|c|c|c|c|}
\hline \multirow{3}{*}{ Variable } & \multicolumn{4}{|c|}{ Individual vulnerability } & \multirow{3}{*}{ p-value } \\
\hline & \multicolumn{2}{|c|}{ Yes } & \multicolumn{2}{|c|}{ No } & \\
\hline & $\mathbf{n}$ & $\%$ & $\mathbf{n}$ & $\%$ & \\
\hline Sex & & & & & 0.115 \\
\hline Female & 139 & 72.4 & 114 & 64.7 & \\
\hline Male & 53 & 27.6 & 62 & 35.3 & \\
\hline Age group & & & & & 0.001 \\
\hline 60 to 69 years & 61 & 31.8 & 108 & 61.5 & \\
\hline 70 to 79 years & 79 & 41.1 & 62 & 35.3 & \\
\hline 80 or more & 52 & 27.1 & 06 & 3.2 & \\
\hline Marital status & & & & & 0.001 \\
\hline Married & 63 & 32.8 & 84 & 47.7 & \\
\hline Widower & 97 & 50.5 & 44 & 25.0 & \\
\hline Single & 22 & 11.5 & 25 & 14.2 & \\
\hline Other & 10 & 5.2 & 23 & 13.1 & \\
\hline Years of schooling & & & & & 0.002 \\
\hline none & 72 & 37.5 & 44 & 25.0 & \\
\hline 1 to 3 years & 47 & 24.5 & 32 & 18.2 & \\
\hline 4 to 8 years & 54 & 28.1 & 66 & 37.5 & \\
\hline 5 years or more & 19 & 9.9 & 34 & 19.3 & \\
\hline Family income & & & & & 0.588 \\
\hline Less than one minimum wage & 6 & 3.1 & 8 & 4.5 & \\
\hline 1 to 3 minimum salaries & 153 & 79.7 & 144 & 81.8 & \\
\hline 3.4 to 5 minimum wages & 26 & 13.5 & 20 & 11.4 & \\
\hline 6 to 10 minimum wages & 7 & 3.7 & 4 & 2.3 & \\
\hline Total & 192 & 100 & 176 & 100 & \\
\hline
\end{tabular}

Regarding sociodemographic characteristics of the 368 older adults who participated in the study, $253(68.8 \%)$ were females. Their ages ranged from 60 to 103 years, with a mean age of 71.4 years and a prevalence of older adults in the age group between 60 and 69 (45.9\%). Regarding marital status, $147(39.9 \%)$ were married, with a schooling level between four and eight years of study (32.6\%) and average family income between 1.1 and 3 minimum wages $(80.3 \%)$, as shown in table 1 .

It was identified that $52.2 \%$ presented individual vulnerability. It should be noted that older adults with a predominant age group between 70 and 79 years were more vulnerable $(p=0.001)$, as well as widowers $(p=0.001)$ and those who did not report schooling level $(p=0.002)$, as shown in table 1 
Table 2 - Association among older adults according to the presence or absence of individual vulnerability and self-reported health problems. João Pessoa, Paraíba, Brazil, 2014 (n = 368)

\begin{tabular}{|c|c|c|c|c|c|c|}
\hline \multirow{3}{*}{ Variable } & \multicolumn{5}{|c|}{ Individual vulnerability } & \multirow{3}{*}{ p-value } \\
\hline & \multirow{2}{*}{$\begin{array}{l}\text { Yes } \\
\text { n }\end{array}$} & \multicolumn{3}{|c|}{ No } & \multirow{2}{*}{$\begin{array}{l}\text { Total } \\
\text { n ( } \%)\end{array}$} & \\
\hline & & $\%$ & $\mathbf{n}$ & $\%$ & & \\
\hline Impaired vision & 169 & 55 & 138 & 45 & $307(100)$ & 0.035 \\
\hline Arterial hypertension & 155 & 55.4 & 125 & 44.6 & $280(100)$ & 0.200 \\
\hline Rheumatism & 100 & 61.7 & 62 & 38.3 & $162(100)$ & 0.001 \\
\hline Memory Problems & 79 & 66.4 & 40 & 33.6 & $119(100)$ & 0.001 \\
\hline Hearing impairment & 67 & 66.3 & 34 & 33.7 & $101(100)$ & 0.001 \\
\hline Diabetes mellitus & 63 & 57.8 & 46 & 42.2 & $109(100)$ & 0.990 \\
\hline Depression & 49 & 51.6 & 46 & 48.4 & $95(100)$ & 0.493 \\
\hline
\end{tabular}

Table 2 shows the relationship between clinical variables. A statistically significant relationship was found between being vulnerable and presenting the following morbidities: rheumatism $(\mathrm{p}=0.001)$, memory problems $(\mathrm{p}=0.000)$ and hearing impairment $(\mathrm{p}=0.001)$.

Table 3 - Distribution of older adults according to self-assessment of health, self-reported difficulty in mobility and in performing activities of daily living. João Pessoa, Paraíba, Brazil, 2014 (n = 368)

\begin{tabular}{|c|c|c|c|c|c|}
\hline \multirow{3}{*}{ Variable } & \multicolumn{4}{|c|}{ Individual vulnerability } & \multirow{3}{*}{ p-value } \\
\hline & \multicolumn{2}{|c|}{ Yes } & \multicolumn{2}{|c|}{ No } & \\
\hline & $\mathbf{n}$ & $\%$ & $\mathbf{n}$ & $\%$ & \\
\hline Self-assessment of health & & & & & 0.001 \\
\hline Bad or regular & 115 & 59.9 & 44 & 25.0 & \\
\hline Good, very good or excellent & 77 & 40.1 & 132 & 75.0 & \\
\hline \multicolumn{6}{|l|}{ Referred Mobility } \\
\hline Bending, kneeling, or squatting & 165 & 62.0 & 101 & 38.0 & 0.001 \\
\hline Lifting or carrying weight of approximately $5 \mathrm{~kg}$ & 146 & 70.5 & 61 & 29.5 & 0.001 \\
\hline Raising or lifting the arm above shoulder level & 89 & 71.2 & 36 & 28.8 & 0.001 \\
\hline Writing or handling small objects & 78 & 67.8 & 37 & 32.2 & 0.001 \\
\hline Walking 400m & 128 & 76.6 & 39 & 23.4 & 0.001 \\
\hline \multicolumn{6}{|l|}{ instrumental activities of daily living } \\
\hline Shopping & 100 & 84.0 & 19 & 16.0 & 0.001 \\
\hline Managing own finances & 92 & 76.0 & 29 & 24.0 & 0.001 \\
\hline Performing simple household chores & 84 & 77.8 & 24 & 22.2 & 0.001 \\
\hline Performing heavy housework chores & 158 & 71.2 & 64 & 28.8 & 0.001 \\
\hline \multicolumn{6}{|l|}{ Instrumental activities of daily } \\
\hline Bathing alone & 71 & 74.7 & 24 & 25.3 & 0.001 \\
\hline Walking across a room unassisted & 49 & 80.3 & 12 & 19.3 & 0.001 \\
\hline
\end{tabular}

*Instrumenal activities of daily; *Basic ADLs.

Considering the data presented in table 3 , we noticed that that bad or regular self-perception of health is more prevalent among vulnerable older adults ( $\mathrm{p}=0.001)$. Regarding mobility, it was evidenced that most of the individuals had difficulties in certain activities such as: bending, kneeling, or squatting $(\mathrm{p}=0.001)$, lifting or carrying weight of approximately $5 \mathrm{~kg}(\mathrm{p}=0.001)$, raising or lifting the arm above shoul- der level $(\mathrm{p}=0.001)$, writing or handling small objects $(p=0.001)$ and walking 400 meters $(p=0.001)$.

Regarding the functional status, decreased performance in instrumental activities of daily life were evidenced, such as shopping $(\mathrm{p}=0.001)$, managing own finances $(p=0.001)$, performing simple household chores $(p=0.001)$ and heavy household chores $(p=0.001)$. 
Regarding the performance of basic activities of daily living, it was shown that vulnerable older adults had difficulty crossing a room and bathing unassisted, $80.3 \%$ and $74.7 \%$, respectively (Table 3 ). We emphasize that the sum of the data presented here represents a higher value than the sample as a result of the same older adult presenting more than one impairment.

\section{DISCUSSION}

Vulnerability can be understood as an association of individual and collective factors that culminates in high susceptibility to illness and death, as well as a lower possibility of coping with life. ${ }^{4}$ It includes aspects that range from biological fragility to the way health programs are arranged, trespassing behavioral, political and cultural issues. In this context, the concept of vulnerability is verified in the necessary utility to understand the specificities that encompass fundamental comprehensive care for the older adult population. ${ }^{4}$

Among older adults interviewed, 52\% were vulnerable, which corroborates findings of other studies in the same field..$^{10-12} \mathrm{~A}$ prospective study conducted in the United States involving 649 older adults from a community showed that those who were 75 years old or older and who scored one point on the VES-13 demonstrated a $5 \%$ probability of death and a $66 \%$ chance of surviving without functional decline in the next five years. On the other hand, older adults who obtained 10 points on the referred scale had a $64 \%$ predicted risk of death and a $10 \%$ chance of surviving without functional decline in the following five years. Thus reaffirming the relevance of early identification of vulnerability in older adults which allows for assisting decision making in the care setting so that these choices are based on functional and specific parameters of the older adults. ${ }^{12}$

Regarding the individual dimension, body changes typical of aging are notorious, resulting from the gradual decline of autopoiesis until total suppression of it, resulting in death. ${ }^{13}$ Thus, through the observed decline in health of older adults over the years, there is a need for implementing theoretical tools and models that allow for identifying the degree of vulnerability and which may lead to more effective interventions based on this detection. Moreover, verifying vulnerability in the older adult population is essential for supporting the nursing team in planning adequate health services and actions aimed at prioritizing preventive care, as well as delaying the onset of health impairment since vulnerable older adults are 4.2 times more likely to die in the subsequent two years after detection. ${ }^{8,10}$

In comparing the socio-demographic data with the occurrence of individual vulnerability among the older adults investigated, a higher prevalence of women was observed when compared to men. This may be linked to the fact that women have greater longevity, which gives them a higher probability of triggering chronic, incapacitating conditions such as osteoarthritis, osteoporosis, hypertension, diabetes mellitus, and depression, among others. ${ }^{14}$ In addition, there are the gender differences experienced throughout the years such as: discrimination, violence, domestic work/chores, as well as educational and professional difficulties. Such experiences lead to increased body changes, so that women deteriorate more than men when considering vulnerability, whether due to chronic conditions or to physical and psychological frailty. ${ }^{16}$

Regarding the age group of the older adults investigated, 70 to 79 years predominated among those who were vulnerable. However, literature shows that this event occurs more frequently among those individuals classified as older elderly who are 85 years or older, as biological variations in addition to physiological stress and exposure to injuries in this population contribute to a greater probability of morbidity and mortality. ${ }^{16}$ In this context, it is worth mentioning that the predominance of younger older adults in the present study may have contributed to a less expressive number of older adults, as can be observed in the results presented here.

Concerning marital status, we found that most of the vulnerable older adults were widowers. The death of a relative can lead to a negative repercussion on health, inducing a condition of social isolation, especially among women; therefore, widowhood is considered a psychosocial stressor. ${ }^{17}$ In contrast, the end of marriage for males whether through divorce or widowhood is not linked to the reduction of survival as observed in older adult women. ${ }^{17-18}$

Widowhood requires changes in lifestyle that require adaptations to new contexts, such as a decrease in social support and material deprivation, which contributes to older adults presenting a 2.5 times greater risk of being dependent and taking less care with their health, thus making them more vulnerable. ${ }^{18-19}$ It is worth mentioning that one way to reduce the negative repercussions of loneliness is to offer older adults a structured social support network that encourages collective living, learning new skills and achieving personal goals. ${ }^{20}$ 
Of the vulnerable older adults investigated, $37.5 \%$ were illiterate. Pertinent literature points to socioeconomic determinants as factors that influence social inequalities, which contribute to establishing inequities in the social context. ${ }^{21}$ Educational deficiencies accumulated over the years compromise access to health education, which impedes adherence to healthy behaviors as well as social movement to improve life circumstances. Consequently, there is an increase in the use of health services by older adults due to the greater prevalence of incapacitating chronic conditions that could have been prevented throughout life. ${ }^{21}$

Data on family income of vulnerable older adults showed that the majority of the aged population had income between one and three minimum wages per month. We emphasize that older people show a higher prevalence of chronic diseases and disabilities, raising challenges for the civil and health systems, especially in reducing social inequalities. ${ }^{21-22}$ A study conducted in England revealed that the influence of income disparities on the functional capacity of older adults has increased in recent years. ${ }^{22}$

In the Brazilian context, due to a reduction in social inequalities in recent years, there was a reduction in the disparity between individual income extremes. However, the magnitude of income inequalities in self-assessment of health and functional capacity of older adults has not changed, demonstrating that income can contribute to establishing individual vulnerability among older adults. ${ }^{23}$

In the context of aging, an association of pathologies causes important impairment to maintaining independence and preserving quality of life. When comorbidities are present, the possibility of functional decline is greater since the ability to compensate for a problem is affected by the condition of accumulating ailments/diseases. ${ }^{24}$ It was evidenced in the present study that by establishing a correlation between the main diseases and individual vulnerability among the older adult population, the occurrence of rheumatism, hearing and memory impairment demonstrated statistically significant associations with the referred event.

This finding confirms the tendency for older adults to more often exhibit multiple morbidities, which in general tend to accentuate over the years and last for long periods, constituting a risk factor for functional decline. ${ }^{25-26}$ Moreover, it is estimated that vulnerability is strongly associated with higher levels of psychological and physical changes and the general well-being of the aged. ${ }^{26}$

Biological aging is a continuous process that causes deleterious effects on the body and has a negative impact on the individual's functional capacity over the years. ${ }^{27}$ Sarcopenia can be highlighted among these changes, defined as a slow, progressive and seemingly inevitable process of loss of strength and muscle mass. It is considered one of the most important physiological changes that occurs with the aging process, since it is responsible for the reduction of muscle strength and power, and consequently for reduced functional mobility in older adults. ${ }^{28}$

In the context of this study, it was identified that vulnerable older adults reported greater difficulty and/or inability to perform certain activities related to mobility, such as bending, kneeling, or squatting; lifting or carrying weight of approximately $5 \mathrm{~kg}$; raising or lifting the arm above shoulder level; and writing or handling small objects. We emphasize that impaired mobility is one of the events that most interferes in the health of older adults, being associated with a scenario of reduced strength and muscular power, incapacity and dependence in performing activities of daily living. ${ }^{28-29}$

Among the problems with advancing age are difficulties in carrying out daily activities, which implies in problems for the older adult and their families, who depending on the activity, will have to organize more time, energy and financial resources to meet the existing demands. ${ }^{28}$ It is observed that for an adequate understanding of the care demands required by the older adult population, periodic evaluations of their health are necessary, including the inherent aspects of their functional capacity. Performance in instrumental and basic activities of daily living has been a widely accepted and recognized parameter for evaluating functional capacity, which can be defined as the concrete possibility of manifesting the physical and mental abilities necessary for an independent and autonomous life..$^{30-32}$

One of the first aspects that is compromised in the aging process is the performance of activities of daily living, mainly because they involve tasks that require greater physical and cognitive integrity, often being related to the individual's social participation such as shopping, answering the phone and using means of transportation. ${ }^{31}$ In the present study and similar to other developed research, it was evidenced that vulnerable older adults reported having difficulty performing the following 
tasks: shopping; managing their own finances and performing household chores. ${ }^{31-32} \mathrm{~A}$ survey carried out in the Netherlands showed that the decline in the performance of instrumental activities varies in the older adult population between $13 \%$ and $24 \%$, resulting in a high burden on social and economic resources. ${ }^{33}$ Regarding the prevalence of dependence for basic activities of daily living, it was noticed that the majority of the older adults investigated had difficulty in bathing alone, which was statistically correlated with vulnerability, indicating a more significant degree of functional dependence.

It is emphasized that individual vulnerability is strongly influenced by the degree of functional dependence of older adults, which may compromise their autonomy, and which is directly related to their ability to perform activities of daily living without help, as well as their freedom to make decisions and the possibility of socially integrating themselves. The severity of this decline is determined by physical damage caused by poor health conditions and by external factors, such as social, financial and family support. $^{24,33}$

Losses from functional decline can be prevented or minimized if the older adult is encouraged to initiate a specific program of physical activities, such as strength and power training, especially of the lower limbs, and under the supervision of properly qualified professionals. Moreover, recognizing and identifying functional changes through simple clinical techniques may favor early intervention and prevent disabilities, especially among older adults with no or only small declines, since they are more likely to benefit from preventive actions. ${ }^{28-33}$

The aging process is initiated from birth and lasts until biological death, permeated by increasing changes which involve a set of individual and collective aspects influencing the life and health conditions of the individual. Increasing implementation of public policies in favor of the older population have been occurring, especially those that propose promotion of active aging through prevention of comorbidities, as well as the maintenance of functional capacity. In order to adequately address vulnerability, nurses need to be able to critically analyze and identify vulnerable older adults at different levels of health care, considering that the aging process is a multidimensional and multi-determined event characterized by vulnerability to biopsychosocial and environmental stressors, as well as changes in body composition, which result in functional impairment and their outcomes.

\section{CONCLUSION}

The findings of this research made it possible to elucidate the prevalence of individual vulnerability in a significant portion of older adults, and the existence of a direct relationship with health indicators. It is worth mentioning that vulnerable older adults were affected by chronic health problems and also demonstrated limitations in their mobility and ability to perform some basic activities of daily living, which influenced the negative self-perception of their health.

We understand that this study contributes to providing care for older adults to be performed by nurses by elucidating solid evidence on the relationship between vulnerability and health problems, an empirical support that can favor political adjustments and health programs for the promoting health, preventing diseases and comprehensive care for the health of older adults.

As a limitation of the study, we can point out the fact that this study was carried out with a population of older adults only attended by Primary Health Care. Therefore, it was not possible to identify other related variables such as the impact of hospitalization on the investigated phenomenon. Considering this, we emphasize the importance of developing further studies with the purpose of presenting new contributions on the subject, and above all elucidating specific interventions that may prevent or minimize the deleterious effects of individual vulnerability among older adults, thereby promoting their well-being, improving their quality of life, and consequently active aging.

\section{REFERENCES}

1. Alvarez AM, Goncalves LHT. Nursing and care for the elderly at home. Rev Bras Enferm. 2012; 6(5):715-6.

2. Cazarim MS, Araújo ALA. O paciente idoso sob o aspecto da utilização de antimicrobianos: repercussão ao sistema público de saúde brasileiro (SUS). Rev Ciênc Farm Básica Apl. 2011;32(3):305-11.

3. Rodrigues NO, Neri AL. Vulnerabilidade social, individual e programática em idosos da comunidade: dados do estudo FIBRA, Campinas, SP, Brasil. Ciênc Saúde Colet.2012;17(8): 2129-39.

4. Ayres JRCM, Calazams GJ, Saletti Filho HC, França Júnior I. Risco, vulnerabilidade e práticas de prevenção e promoção da saúde. In: Akerman M, Campos GWS, Carvalho YM, Drumond Júnior M, Minayo MCS. Tratado de saúde coletiva. $2^{\mathrm{a}}$ ed. São Paulo: Hucitec; 2012. P. 375-416.

5. Mariano PP, Baldissera VDA, Martins JT, Carreira L. Nursing work organization in long-stay institutions 
for the elderly: relationship to pleasure and suffering at work. Texto contexto enferm. [Internet]. 2015 [cited 2015 Oct 23];24(3):756-65. Available from: http://www.scielo.br/scielo.php?script=sci_ arttext\&pid=S0104-07072015000300756\&lng=pt.

6. Silva SH, Silva LTB, Barros TC, Oliveira EM, Ordonez TN, Carvalho G, et al. Vulnerabilidade na velhice: definição e intervenções no campo da Gerontologia. RKG [Internet]. 2012 [cited 2016 Feb 10];15(6):97-116. Available from: http:/ / revistas.pucsp.br/index.php/ kairos/article/view/17289/12829

7. Bertolucci PHF, Brucki SMD, Campacci SR, Juliano Y. O mini-exame do estado mental em uma população geral: impacto da escolaridade. Arq Neuropsiquiatr. [Internet]. 1994 [cited 2015 Oct 23];52(1):17. Available from: http://dx.doi.org/10.1590/ S0004282X1994000100001

8. Maia FOMM, Duarte YAO, Secoli SR, Santos JLF, Lebrao ML. Cross-cultural adaptation of the Vulnerable Elders Survey-13 (VES-13): helping in the identification of vulnerable older people. Rev Esc Enferm USP.2012; 46(n especial):116-2.

9. Ministério da Saúde (BR). Conselho Nacional de Saúde. Resolução n ${ }^{\circ}$ 466, de 12 de dezembro de 2012. Diretrizes e normas regulamentadoras de pesquisas envolvendo seres humanos. Diário Oficial da União da República Federativa do Brasil. 2013 jun 13; 150(112) Seção 1:59-62.

10. Luciani A, Ascione G, Bertuzzi C, Detecting disabilities in older patients with cancer: comparison between comprehensive geriatric assessment and vulnerable elders survey-13. J Clin Oncol. 2010;28(12):2046-50.

11. Arora VM, Fish M, Basu A, Olson J, Plein C, Suresh K, Sachs G, Meltzer DO. Relationship between quality of care of hospitalized vulnerable elders and postdischarge mortality. J Am Geriatr Soc.2010; 58:1642-48.

12. Castagneto B, Di Pietrantonj C, Stevani I, Anfossi A, Arzese M, Giorcelli L, Giaretto L. The importance of negative predictive value (NPV) of vulnerable elderly survey (VES13) as a pre-screening test in older patients witha cancer. Medical Oncology. 2013;30(4):2-5.

13. Simões ACA, Carvalho DM. A realidade da saúde bucal do idoso no sudeste brasileiro. Ciênc Saúde Coletiva. 2011;16(6):2975-82.

14. Rubio E, Comín M, Montón G, Martínez T, Magallón $\mathrm{R}$, Carcía-Campayo J. Determinantes de la capacidad funcional en personas mayores según el gênero. Gerokomos. 2013; 24(2): 69-73.

15. Nicodemo D, Godoi M P. Juventude dos anos 60-70 e envelhecimento: estudo de casos sobre feminização e direitos de mulheres idosas. Rev Cienc Ext. 2010;6(1):40-53

16. Amendola F, Alvarenga MRM, Latorre MRDO, Oliveira MAC. Development and validation of the Family Vulnerability Index to Disability and
Dependence (FVI-DD). Rev Esc Enferm USP. 2014;48(1): 80-8.

17. Nunes MCR, Ribeiro RCL, Rosado LEFPL, Franceschini SC. The influence of sociodemographic and epidemiological characteristics on the functional capacity of elderly residents in the city of Ubá, Minas Gerais. Rev Bras Fisioter. 2009;13(5):376-82.

18. Gomes MMF, Turra CM, Fígoli MGB, Duarte YAO, Lebrão ML. Associação entre mortalidade e estado marital: uma análise para idosos residentes no município de São Paulo, Brasil, Estudo SABE, 2000 e 2006. Cad Saúde Pública. 2013;29(3):566-78.

19. Virtuoso Júnior JS, Guerra RO. Incapacidade funcional em mulheres idosas de baixa renda. Ciênc Saúde Coletiva. 2011;16(5): 2541-8.

20. Guerra ACLC, Caldas CP. Dificuldades e recompensas no processo de envelhecimento: a percepção do sujeito idoso. Ciênc saúde coletiva.2010;15(6): 2931-40.

21. Geib LTC. Determinantes sociais da saúde do idoso. Ciênc Saúde Coletiva. 2012;17(1):123-33.

22. Martin LG, Schoeni RF, Andreski PM, Jagger C. Trends and inequalities in late-life health and functioning in England. J Epidemiol Community Health. 2011;66(10):874-80.

23. Lima-Costa MF, Facchini LA, Matos DL, Macinko J. Mudanças em dez anos das desigualdades sociais em saúde dos idosos brasileiros (1998-2008). Rev Saúde Pública. 2012;46(11):100-7.

24. Daniels R, Van Rossum E, Beurskens A, Van Den Heuvel W, de Witte L. The predictive validity of three self-report screening instruments for identifying frail older people in the community. BMC Public Health. 2012;12(69):2-7.

25. Alve, LC, Leite IC, Machado CJ. Factors associated with functional disability of elderly in Brazil: a multilevel analysis. Rev Saúde Pública.2010; 44(3): 468-78.

26. Myall BR, Hine DW, Marks ADG, Thorsteinsson EB, Toussaint MB, Samuels CA. Assessing individual differences in perceived vulnerability in older adults. Pers Individ Dif.2009;46:8-13.

27. Teixeira INAO, Guariento ME. Biologia do envelhecimento: teorias, mecanismos e perspectivas. Ciênc Saúde Coletiva. 2010;15(6):2845-57.

28. Garcia PA., Dias JMD, Dias RC, Santos P, Zampa CC. A study on the relationship between muscle function, functional mobility and level of physical activity in community-dwelling elderly. Rev Bras Fisioter. 2011;15(1):15-22.

29. Van Iersel MB, Munneke M, Esselink RA, Benraad CE, Olde Rikkert MG. Gait velocity and the Timed-Upand-Go Test were sensitive to changes in mobility in frailelderly patients. J Clin Epidemiol. 2008;61(2):186-91

30. Barbosa KTF, Melo MGF, Oliveira FMRL, Santos $\mathrm{KOF}$, Pereira MA. Fall in the elderly: association with morbidity and functional capacity. Journal of Nursing UFPE on line. 2013;7(8):5068-75. 
31. Ursine PGS, Cordeiro HÁ, Moraes CL. Prevalence of housebound elderly people in the urban region of Belo Horizonte (Minas Gerais, Brazil). Ciênc Saúde Coletiva.2011;16(6):2953-62.

32. Del Duca GF, Silva MC, Hallal PC. Disability relating to basic and instrumental activities of daily living among elderly subjects. Rev Saúde Pública.2009;43(5):796-805.

33. Suijker JJ, Buurman BM, Van Rijn M, Van Dalen MT, Ter Riet G, Van Geloven N, et al. A simple validated questionnaire predicted functional decline in community-dwelling older persons: prospective cohort studies. J Clin Epidemiol. 2014;67(10):1121-30.

34. Lachman ME, Agrigoroaei S. Promoting functional health in midlife and old age: longterm protective effects of control beliefs, social support anda physical exercise. Plos ONE. 2010; 5(10):1-9.

35. Andrade AN, Fernandes MGM, Nóbrega MML, Ribeiro TG, Costa KNFM. Frailty in the elderly: conceptual analysis. Texto Contexto-enferm [Internet]. 2012 [cited 2015 Jun 28]; 21(4):748-56. Available from: http:// dx.doi.org/10.1590/S0104-07072012000400004. 